Conference Paper

\title{
Analysis of Factors Affecting Capital Buffer in Sharia Commercial Banks in Indonesia
}

\author{
Sri Muljaningsih*, Muchtolifah, Kiky Asmara \\ Development Economics Study Program, Universitas Pembangunan Nasional "Veteran” Jawa Timur, Indonesia
}

*Corresponding author:

E-mail: muljaningsihsri@gmail.com

\begin{abstract}
Capital buffer serves to anticipate the risk of unexpected banking systemic risks. Capital buffer is derived from the difference between banks' capital adequacy ratio (CAR)and the minimum capital adequacy ratio (minimum CAR) regulated by policymakers. This research is made to know what factors affect capital buffer in Indonesia Islamic Commercial banks. These factors include Return On Equity (ROE), Non-Performing Finance (NPF), Financing to Deposit Ratio (FDR), and Gross Domestic Product (GDPG). This study uses secondary data obtained from the official website of OJK, the official website of the Islamic banks, and BPS Agency for a period of 5 years in 2014-2018 on quarterly data. The analysis technique used is Multiple Linear Regression Analysis. The results show that the Return on Equity (ROE), Non-Performing Finance (NPF), Financing to Deposit Ratio (FDR), and Gross Domestic Product (GDPG) affected Capital Buffer in Islamic Commercial Banks in Indonesia simultaneously. While it is partially obtained that the Financing to Deposit Ratio (FDR) variable has a significant and negative effect on the Capital Buffer. Return On Equity (ROE) and Non-Performing Finance (NPF) has insignificant and negative effects on the capital buffer. Gross Domestic Product Growth has an insignificant and positive effect on the capital buffer at Islamic Commercial Banks in Indonesia.
\end{abstract}

Keywords: Capital Buffer, Return on Equity (ROE), Non-Performing Finance $(N P F)$, Financing to Deposit Ratio (FDR), Gross Domestic Product growth $(G D P G)$

\section{Introduction}

Banks in carrying out their functions as intermediation have many risks, especially in times of crisis. If the risk is realized, the bank will suffer losses on credit activities or other activities. Therefore, banks should have a form of anticipation in the management of adverse risks, the form of anticipation is in the form of buffers as safety in the face of risks to such losses.

Banks must have sufficient capital to maintain the level of customer confidence in banking activities. Bank Indonesia as the Central Bank is the regulator has the authority to supervise the banking industry by issuing banking rules on capital. Bank Indonesia implements the principle of prudence in setting minimum capital obligations that must be owned by banks. It aims to strengthen the banking system and minimize potential losses.

The basic regulation used by Bank Indonesia through the Financial Services Authority is to apply the international banking regulation, Basel Committee on Banking Supervision (BCBS). In 1988 BCBS issued an initial concept on bank capital along with calculation of Risk-Weighted Assets (ATMR) specifically for credit risk which was later refined in 1996 by adding Tier 3 and ATMR market risk. The concept of capital issued by BCBS is more Basel Accord I wherein the rules the bank is obliged to have three main objectives in developing Basel I namely:

1. To strengthen the constraints and stability of the international banking system

2. Create a fair framework for measuring the capital adequacy of international banks.

How to cite:

Muljaningsih, S., Muchtolifah, \& Asmara, K. (2021). Analysis of factors affecting capital buffer in Sharia Commercial Banks In Indonesia. $3^{\text {rd }}$ Economics, Business, and Government Challenges 2020. NST Proceedings. pages 46-52. doi: 10.11594/ nstp.2021.1307 
3. Strive to develop a framework that can be implemented consistently to reduce competition among international banks.

In 2006 BCBS issued a rule regarding Basel II. The rules of Basel Accord II are considered more complex than Basel I. In Basel II there is a capital calculation framework that is more sensitive to risk. Basel II aims to improve the security and health of the financial system focusing on risk-based capital calculations, supervision review processes, and market discipline. In general, Basel II framework consists of three pillars, namely: Pillar 1 on minimum capital requirements, Pillar 2 on the supervisory review process, and Pillar 3 related to market discipline. With the implementation of Basel II in banking in Indonesia, it is expected that the banking industry in Indonesia will be healthier and able to survive in crisis conditions.

The global financial crisis of 2008/2009 prompted BCBS to issue Basel III policy or global financial reforms to strengthen resilience on the macroprudential and macroprudential side. Increasing resilience in the macroprudential side by looking at the quantity and quality of bank capital and the need for adequate capital reserves (buffers) owned by banks and requiring the establishment of conservation buffers of $2.5 \%$ of risk-weighted assets (ATMR) owned by banks, the buffer is useful to absorb losses in the event of a crisis. Meanwhile, increased macroprudential resilience by reforming the procyclicality of the financial system. Macroprudential strengthening is a requirement of banks in providing countercyclical capital buffers at a time of good economic conditions (boom period) aimed at absorbing losses in the event of a crisis (boost period), due to the result of excessive credit growth which disrupted the financial system.

In this case, one of the sharia commercial banks in 2019 had difficulty in its liquidity, because in this case, the bank took the wrong business model. Where the bank concentrates on large-scale corporate financing compared to other market players such as retail and consumption. This financed corporation operates in the oil palm plantation and coal mining sectors, whereas at that time market conditions in this sector were in a cycle of declining commodity prices tend to decline amid weakening market demand. At that time, the global economy was uncertain, which could be that many countries were maintaining the stability of each country's economy which did not do many economic activities between countries. So, the company had difficulty in returning installments, which resulted in the bank's activities being disrupted.

From the above case, that the bank does not rely only on CAR reserves. Therefore, it is necessary to value or reserve a capital buffer that serves as an anticipation of the state of the bank in the crisis period. This crisis period refers to a high level of liquidity that is not balanced with the quality of assets owned by a bank. The amount of capital buffer value of 0\%-2.5\% comes from the difference between the CAR owned by the bank and the minimum CAR. Car value exceeds an average of $8 \%$ according to each bank's risk profile, the amount has exceeded the capital buffer value provision of $0 \%-2.5 \%$. This raises questions about what factors influence the amount of capital that banks must hold that will affect the bank's capital level.

There have been several previous studies on several factors that affect capital buffers, among others: d'Avack and Levasseur (2007), Prasetyandoko and Soedarmono (2010), Atici and Gursoy (2012), and Iqbal (2018). This study has various research results including Return on equity (roe), non-performing finance (npf), financing to deposit ratio (fdr), and gross domestic Product (GDPG).

\section{Literature Review Capital buffer}

Mishkin (2008) stated that the bank withheld its capital for several reasons. First, capital aims to anticipate failure, the bank withholds its capital to reduce the risk of not being solvable or absorbing losses. Second, the amount of capital affects shareholder returns. The greater the capital held the fewer profit shareholders receive. Third, meet the minimum capital of banks regulated by regulators. Therefore, having a sufficient capital buffer can serve as a buffer against the possibility of risk. Sufficient capital buffer level, banks will become better prepared to face various risks that will occur in the future.

According to Jokipii and Milne (2008), the capital buffer is the amount of bank capital held more than the number of needs specified by national regulations or known as the Minimum Mandatory Giro 
(GWM). In other words, the capital buffer is the difference between the Capital Adequacy Ratio (CAR) or capital adequacy ratio of each bank with a minimum CAR set by banking regulation of $8 \%$. Prasetyantoko and Soedarmono (2010) also define the capital buffer as a risk-based adequacy ratio of less than $8 \%$, since the minimum capital requirement is subject to an equally large $8 \%$ for all banks according to Basel I.

Capital Buffer has a function to reduce due to unexpected systemic risks. These unexpected systemic risks include crisis, disruption of financial stability of political and state conditions. With the Regulation ofOtoritas Jasa Keuangan No.21/POJK.03/2014 is expected to be able to control the condition.

\section{Return On Equity (ROE)}

ROE is a ratio usually used to measure a bank's financial performance. This ratio serves to measure the ability of bank management in managing existing capital to earn net income. ROE is a ratio that indicates the bank's ability to generate a profit using its equity. The higher the ROE of a company, the more efficient the company is using its capital to earn a net profit, resulting in increased income and affect dividend payments (especially in banks that go-public).

Ayuso et al. (2004) and Jokipii and Milne (2008) used Return On Equity (ROE) as a proxy for the cost of holding capital. ROE can also exceed the remuneration demanded by shareholders and has so far been used for revenue-over-cost measurement. ROE growth indicates the company's better prospects due to the potential for increased profits obtained by the company. The higher the ROE, the greater the capital buffer provided by the bank. Where the bank holds a high profit as a buffer (reserve) for the bank so that if in the future there is a shock, the bank will be strong and still be able to carry out its business activities. This is following Basel III Regulation based on capital-based safety and following the results of research from Bayuseno and Chabahib (2014), Fauzia and Idris (2016) and Purwati et al. (2016) found a positive relationship between ROE and capital buffer.

\section{Non-Performing Finance (NPF)}

Non-Performing Loans are a ratio to measure risk to credit disbursed by comparing bad loans with the amount of credit disbursed. Ayuso, et al. (2004), and Jokipii and Milne (2008), used the Non-Performing Loans (NPL) indicator as a proxy for the cost of financial distress. Large NPLs show great risk, banks with large NPLs tend to be inefficient. The higher the NPL a bank shows the higher the risk. High NPLs are not only related to bank management but can also be caused by worsening economic changes, thereby impacting the business conditions of debtors.

Referring to Bank Indonesia Regulation No.9/1/PBI/2007, Non-Performing Finance (NPF) is measured from 3 categories of non-performing loans namely KL (Less Current), D (Doubtful), and M (Bad) including Non-Performing Financing divided by total loans. The higher the number of Non-Performing Funding will increase costs, thus potentially causing losses. Following Bank Indonesia regulations, the safe amount of Non-Performing Loans (NPL) is below 5\% (five percent).

\section{Financing to Deposit Ratio (FDR)}

The FDR ratio is a ratio that measures the comparison of the amount of financing provided by banks with funds received by banks, which illustrates the ability of banks to repay withdrawals by depositors by relying on the financing provided as a source of liquidity. Therefore, the higher the ratio indicates the bank's low liquidity ability. This is as a result of the number of funds needed to finance the financing becomes larger. This ratio is also an indicator of the insecurity and ability of a bank. Some practitioners agree that the safe limit of financing to deposit ratio of a bank is about $80 \%$. But the tolerance limit is between $85 \%$ and $100 \%$.

\section{Gross Domestic Product Growth (GDPG)}

Economic growth is defined as an increase in GDP (Gross Domestic Product) regardless of whether the increase is greater or less than the population growth and regardless of whether there is a change in its economic structure.

Meanwhile, according to some economists, the sense of economic growth is an increase in the value of GDP regardless of whether the increase is greater or less than the rate of population growth. In 
more general use, the term economic growth is usually used to declare activities in developed countries (Sukirno, 2016).

GDP is a price index that measures the price level of several goods produced in an economy purchased by households, companies, governments, and abroad (Nanga, 2005).

GDP is also the value of goods and suits produced in the country using production factors owned by the country's residents and residents/companies of other countries (Sukirno, 2016)

GDP is the amount of added value generated by all business units in a particular country within a certain period. The amount of the value of the final goods and services provided from the product must be equal to the value of the goods used. GDP can also be used to determine the price change with calculates the GDP deflator (implicit index change). The implicit price index is the ratio between GDP by prevailing price and GDP by constant price.

\section{Hypothesis}

1. There is an influence between Return on Equity (ROE) on Capital Buffer.

2. There is an influence between Non-Performing Finance (NPF) on Capital Buffer.

3. There is an influence between Financing to Deposit Ratio on Capital Buffer There is an influence between Gross Domestic Product Growth (GDPG) on Capital Buffer

\section{Research Methods}

The data used in this research is secondary data in the form of time-series data, quantitative for the last 5 years, namely 2014-2018. Sampling using purposive sampling techniques. According to Sugiyono (2016), the Purposive Sampling Technique is a data source sampling technique with certain considerations. The reason for using the purposive sampling technique is because not all samples have criteria that match the phenomenon or data obtained in the study.

To find out the effect of ROE, NPF, FDR, and GDPG variables on Capital Buffer on Sharia Commercial Banks in Indonesia. Quantitative analysis used in this study included the coefficient of determination (R2) test, classical assumption test, multiple linear regression analysis, and hypothesis test. This research uses computer software program SPSS (Statistical Program For Social Science) 25.0 for windows

Quantitative analysis used in this study includes classic assumption tests, multiple linear regression analyses, and hypothesis tests. Models of multiple linear regression equations defined as follows:

$Y=\beta_{0}+\beta_{1} X_{1}+\beta_{2} X_{2}+\beta_{3} X_{3}+\beta_{4} X_{4}+€$

Information:

Y: capital buffer

$\mathrm{X} 1$ : return on equity

$\mathrm{X} 2$ : non-performing finance

$\mathrm{X} 3$ : financing to deposit ratio

$\mathrm{X} 4$ : gross domestic product growth

$\beta 0$ : Constanta

$\beta(1,2,3,4)$ : regression coefficient

\section{Results and Discussion}

\section{Description of research object}

Data In this study the population used is all sharia commercial banks in Indonesia registered by the Financial Services Authority. The research period for 5 years starting from 2014-2018 using quarterly data (every three months). So, there are 4 Quarters each year. There are 11 sharia commercial banks starting from 2014-2018. However, the samples used in the study were 7 sharia commercial banks that met the research criteria.

This research data is obtained from financial statements that have been published by each sharia commercial bank. 
Multiple regression analysis

Table 1. Multiple regression analysis results

\begin{tabular}{llll}
\hline Model & \multicolumn{2}{l}{ Unstandardized Coefficients } & \multicolumn{2}{l}{ Standardized Coefficients } \\
\cline { 2 - 4 } & $\mathrm{B}$ & Std. Error & Beta \\
\cline { 2 - 4 } Constant $)$ & 30.694 & 4.871 & \\
X1(ROE) & -.123 & .826 & -.027 \\
$\mathbf{X 2}(\mathbf{N P F})$ & -.187 & .623 & -.057 \\
$\mathbf{X 3 ( F D R )}$ & -.224 & .056 & -.750 \\
$\mathbf{X} 4($ GDPG $)$ & .167 & .198 & .170 \\
\hline
\end{tabular}

Source: BPS and SPSS

$\mathrm{Y}=30,694-0,123 \mathrm{X} 1-0,187 \mathrm{X} 2-0,224 \mathrm{X} 3+0,167 \mathrm{X} 4$

\section{Determination coefficient Test $\left(R^{2}\right)$}

Based on R2 test results, it was concluded that the value of $\mathrm{R} 2$ is 0.553 or $55.3 \%$. This means that the value of 55.3\% of independent variables (ROE, NPF, FDR, and GDPG) can explain dependent variables (capital buffers) and the remaining $44.7 \%$ is described other variables that are not included in this research model.

\section{Hypothesis test}

Table 2. Test Result t

\begin{tabular}{lllll}
\hline Variabel & $\mathrm{T}$ & $\mathrm{t}$-tabel & $\mathrm{Sig}$ & Conclusion \\
\hline ROE & $-0,149$ & 2,13145 & 0,884 & Insignificant \\
NPF & $-0,301$ & 2,13145 & 0,768 & Insignificant \\
FDR & $-3,988$ & 2,13145 & 0,001 & Significant \\
GDPG & 0,847 & 2,13145 & 0,410 & Insignificant
\end{tabular}

Source: BPS and SPSS

\section{Discussion}

The effect of ROE, NPF, FDR, and GDPG on Capital Buffers

In independent variables, Return on Equity, Non-Performing Finance, Financing to Deposit Ratio and Gross Domestic Product Growth can explain dependent variables namely Capital Buffer of 55.3\%, while the remaining $44.7 \%$ is explained by other factors/variables not included in the research model.

In part, FDR has a negative and significant effect on capital buffers. While ROE, NPF, and GDPG have no significant effect on capital buffers.

The effect of return on equity on capital buffer

Based on the test results obtained for the Variable Return On Equity it is known that the regression coefficient is negative and insignificant. This is following the research of Fikri (2012), Iqbal (2018), in 
his research shows that roe is negative and insignificant meaning that the lower the ROE level owned by the bank, the higher the capital buffer level but is weak. In this case, ROE does not contribute to an increase in the amount of retained earnings, so banks prefer external funding by issuing equity to additional capital. In this study, equity issuance described profitability utilized by banks as (reserve) capital buffers where the reserves can be made if the shock occurs in the future.

\section{The effect of non-performing finance on capital buffer}

Based on the test results obtained Non-Performing Finance variables are known that the regression coefficient is negative and insignificant. The value of NPF is negative and insignificant which means that the lower the NPF owned by the bank, the higher the capital buffer level but is weak. According to D'Avack and Levasseur (2007) that there is a negative relationship between NPF to capital buffers due to "moral hazard" behavior were with a higher level of risk, banks tend to hold a low capital buffer. This is because banks do not apply the principle of prudence in disbursing credit. The high level of NPF will reduce the level of capital buffer owned by the bank.

\section{The effect of financing to deposite ratio on capital buffer}

Based on the test results obtained for the Variable Financing to Deposite Ratio it is known that the regression coefficient is negative and significant. This result is consistent with Iqbal's research (2018) which shows that the lower the level of FDR feeding will be the higher the capital buffer level and stronger. FDR is used to determine the credit ratio by comparing the total deposit and capital owned by the bank. The negative relationship between FDR and capital buffers indicates that the risk of banks is greater by risking deposits and capital owned. So that the high FDR will be able to reduce the level of capital owned by banks that will directly affect (reserve) capital buffers. So that means a high FDR level will reduce the capital buffer level.

\section{The effect of gross domestic product growth on capital buffer}

Based on the test results obtained for the Gross Domestic Product Growth variable it is known that the regression coefficient is positive and insignificant. The higher the GDPG level, the lower the capital buffer level. While in this study shows that the higher the GDPG level, the higher the capital buffer level but is weak. GDPG has a positive influence because in the condition of the country's economy is improving it will increase the capital buffer. This is due to the good condition of economic actors and leads to credit financing aka running smoothly as well as the repayment of credit financing provided by banks. The profit on credit activities and equity issuance will increase the amount of capital that will increase (reserves) capital buffer.

\section{Conclusion}

1. Return On Equity does not contribute to Capital Buffer to Sharia Commercial Banks in Indonesia. This is because the ROE level will still increase the amount of Capital Buffer derived from retained earnings which will be the initial capital in the next period.

2. Non-Performing Finance does not support Capital Buffer at Sharia Commercial Banks in Indonesia. This is due to the level of NPF owned by Sharia Commercial Banks, no increase is still in the category of good enough so that the NPF ratio does not affect the Capital Buffer.

3. Financing to Deposite Ratio has a significant and negative influence on Capital Buffer in Sharia Commercial Banks in Indonesia. This is due to the decrease in FDR ratio will increase Capital Buffer, low FDR ratio rate will result in low risk of NPF in the bank, so that what happens to the bank experience maximum profit/income.

4. Gross Domestic Product Growth does not directly support capital buffers. This is because the value of GPDG will affect directly if the bank contributes to companies that have large scale in terms of financing or funds disbursed, while in Sharia Commercial Banks that are able in terms of financing this is only a minority because sharia commercial banks at that time the majority are still in Basel I and II. 


\section{References}

Atici, G., \& Gursoy, G. (2013). The determinants of capital buffer in the Turkish banking system. International Business Research, 6(1), 1-10. Ayuso, J., Perez, D., \& Saurina, J. (2004). Are capital buffers pro-cyclical? Evidence from Spanish panel data. Jurnal Keuangan Menengah, 13, 249-264.

Bayuseno, V., \& Chabahib, M. (2014). Analisis faktor yang mempengaruhi capital buffer perbankan di Indonesia (Studi pada bank-bank konvensional go public periode 2010-2013). Diponegoro Journal of Management, 3(4), 1-7.

D'Avack, F., \& Levasseur, S. (2007). The Determinants of Capital buffers in CEECs (Central and Eatern European Countries). Observatoire Francais des Conjoctures Economiques.

Fauzia, N. A., \& Idris. (2016). Analisis faktor-faktor yang mempengaruhi capital buffer (Studi kasus pada bank umum konvensional yang terdaftar di Bursa Efek Indonesia Periode 2011-2014. Diponegoro Journal of Management, 5(2), 1-5.

Fikri, M. R. (2012). Determinants of commercial bank' s capital buffer in Indonesia. Diponegoro Journal of Management, 1(2), 1-9. Iqbal, M. (2018). Faktor-faktor yang mempengaruhi capital Buffer Pada Bank Umum Syariah di Indonesia. Jakarta: UIN Jakarta Press. Jokipii, T., \& Milne, A. (2008). The cyclical behaviour of european bank capital buffers. Journal of Banking and Finance, $1440-1451$.

Mishkin, F. S. (2008). Ekonomi uang, perbankan dan pasar uang, Buku 1. Jakarta: SalembaEmpat

Nanga, M. (2005). Makro Ekonomi: Teori masalah dan kebijakan. Jakarta: PT Grafindo Persada

Prasetyandoko, A., \& Soedarmono, W. (2010). The determinants of capital buffer in Indonesia banking. Financing Stability Review, May 18

Purwati, J., Sudarto, \& Suwaryo. (2016). Analisis hubungan jangka panjang dan jangka pendek antara NPL, ROE, SIZE dan LOTA terhadap Capital Buffer. Business \& Management Journal, 22(2), 1-6.

Sukirno, S. (2016). Teori pengantar makro ekonomi Edisi Ketiga. Jakarta: Rajawali Pers 